\title{
Analisis Hubungan Permainan Bisik Berantai Terhadap Kemampuan Berbahasa Anak Usia Dini
}

\author{
Anggun Kartika Putri ${ }^{1)^{*}}$, Renti Oktaria ${ }^{1)^{*}}$ \\ ${ }^{1}$ FKIP, Universitas Lampung, Jl. Prof. Dr. Ir. Sumantri Brojonegoro No.1 \\ *email: anggun.kartika4008@ students.unila.ac.id
}

Abstract. Analysis of the Relationship of Whispering Serial Games on Early Childhood Language Ability. This study is based on a literature review related to early childhood development aimed at explaining the relationship of serial whisper play to early childhood abilities, sourced from: 1) abstract research results, 2) journal reviews, 3) reference books. One method that can be used in supporting early language development is through play methods, namely through serial whisper games to overcome various problems in the development of the language used today as well as the learning used is still focused on calistung and used monotone. Through serial whisper games can improve the ability to convey the words needed in messages and improve the ability of children to overcome or listen to the strengths of others, improve children's memory abilities, and add many new words to children. From the exposure that has been published about serial whisper games is one of the effective games used to improve abilities in early childhood.

Keywords: chain whisperer, language skills, early childhood

\begin{abstract}
Abstrak. Analisis Hubungan Permainan Bisik Berantai Terhadap Kemampuan Berbahasa Anak Usia Dini. Studi ini didasarkan pada kajian pustaka terkait perkembangan bahasa anak usia dini yang bertujuan untuk menjelaskan hubungan permainan bisik berantai terhadap kemampuan berbahasa anak usia dini, dengan bersumber pada: 1) abstrak hasil penelitian, 2) review jurnal, 3) buku referensi. Salah satu metode yang dapat digunakan dalam mendukung meningkatnya perkembangan bahasa anak usia dini adalah melalui metode bermain, yaitu melalui permainan bisik berantai untuk mengatasi berbagai permasalahan dalam aspek perkembangan bahasa yang dewasa ini masih sering terjadi seperti pembelajaran yang diterapkan masih terfokus pada calistung dan cenderung monoton. Melalui permainan bisik berantai dapat meningkatkan kemampuan berbahasa dalam menyampaikan kata yang terdapat di dalam pesan serta meningkatkan kemampuan anak dalam memahami atau menyimak perkataan orang lain, meningkatkan kemampuan daya ingat anak, dan menambah banyak kosa kata baru bagi anak. Dari pemaparan yang telah dijabarkan bahwa permainan bisik berantai merupakan salah satu permainan yang efektif dapat digunakan untuk meningkatkan kemampuan berbahasa pada anak usia dini.
\end{abstract}

Kata kunci: permainan bisik berantai, kemampuan berbahasa, anak usia dini 


\section{PENDAHULUAN}

Anak usia dini merupakan seseorang yang mengalami proses tumbuh dan kembang yang sangat pesat pada rentang usia anak 0-8 tahun. Anak usia dini memiliki pola tumbuh kembang dalam enam aspek yaitu kognitif, sosial emosional, fisik motorik, nilai moral agama, seni, dan bahasa. Pertumbuhan dan perkembangan anak tersebut akan menjadi penentu dalam kehidupan anak selanjutnya. Hal tersebut diperkuat dengan pendapat NAEYC (Hartati, 2005) anak usia dini adalah sekelompok individu yang berada pada rentang usia anatara 0-8 tahun. Anak usia dini merupakan kelompok manusia yang berada dalam proses pertumbuhan dan perkembangan. Hal ini mengisyaratkan bahwa anak usia dini adalah individu yang unik di mana anak memiliki pola pertumbuhan dan perkembangan dalam enam aspek yang khusus sesuai dengan tahapan yang sedang dilalui oleh anak tersebut. Pada masa pertumbuhan dan perkembangan anak usia dini berada pada masa emas atau yang biasa disebut dengan masa golden age, karena pada masa tersebut pertumbuhan dan perkembangan anak yang telah lewat tidak dapat terulang kembali pada masa mendatang. Menurut berbagai penelitian dalam bidang neurologi terbukti bahwa 50\% kecerdasan anak terbentuk dalam kurun 4 tahun pertama, setelah anak berusia 8 tahun perkembangan otaknya mencapai $80 \%$ dan pada usia 18 tahun $100 \%$ Suyanto (Pebriana, 2017). Selain itu Hartati (2005) menambahkan pandangan Johann Heinrich Pestalozi yang sangat relevan dalam pendidikan anak usia dini adalah konsep pembelajaran yang menekankan pada: 1) suara, 2) bentuk, 3) bilangan. Ke tiga konsep yang dikemukan oleh Pestalozi tersebut amat erat dekat kaitannya pada dimensi auditori, visual, dan memori yang tepat digunakan selama masa perkembangan anak usia dini. Dari pendapat Pestalozi bahwa pendidikan anak usia dini amat erat kaitannya dengan salah satu aspek perkembangan anak yakni aspek perkembangan bahasa pada anak usia dini.

Perkembangan bahasa pada anak usia dini merupakan salah satu faktor yang memberikan pengaruh bagi semua aspek perkembangan anak terutama aspek perkembangan kognitif dan hal tersebut akan berdampak dengan keberhasilan anak di masa selanjutnya, semakin meningkat tumbuh kembang anak serta kemampuan anak dalam memahami lingkungan maka kemampuan berbahasa anak usai dini juga semakin mengalami peningkatan dalam perkembangannya dari yang sederhana ke tingkat yang lebih kompleks. Departemen Pendidikan dan Kebudayaan (Mulyati, 2012) menyatakan bahwasannya kemampuan berbahasa di lembaga PAUD mempunyai arti penting baik di lingkungan anak sendiri dengan temannya maupun dengan lingkungannya dan di dalam pengembangan pendengaran, informasi yang disampaikan jelas, tepat, dan singkat. Sejalan dengan pendapat tersebut bahasa adalah penghubung atau sebagai alat komunikasi anak dengan lingkungannya, baik itu orang dewasa maupun teman sebaya yang ada di lingkungan anak. Perkembangan bahasa pada anak sangat dipengaruhi oleh faktor lingkungan, karena kemampuan berbahasa bukan hal yang langsung dapat dengan mudah dikuasai oleh anak. Akan tetapi kemampuan berbahasa secara tidak langsung diperoleh anak melalui lingkungan. Melalui interaksi yang dilakukan oleh anak. Peranan bahasa sangat penting dalam kehidupan sehari-hari. Suhartono (Pebriana, 2017) menyatakan beberapa peranan bahasa bagi anak usia dini yaitu sebagai berikut, 1) sebagai sarana untuk berfikir, 2) sarana untuk mendengarkan, 3) sarana untuk berbicara, dan 4) sarana agar anak mampu membaca dan menulis.

Berkaitan dengan perkembangan bahasa berdasarkan beberapa jurnal penelitian, permasalahan yang sering kali terjadi dalam satuan PAUD adalah bahwa kemampuan berbahasa anak masih kurang dan anak masih mengalami kesulitan dalam berbahasa. Hal tersebut disebabkan oleh beberapa hal, yang menjadi faktor terjadinya permasalahan tersebut yaitu, seperti anak kesulitan dalam mengungkapkan apa yang dibicarakan oleh guru, merasa bingung dengan kata yang diucapkan temannya, kurang baik dalam pengucapan kata atau 
huruf, keterbatasan media yang digunakan oleh guru, selain itu dalam pembelajaran bahasa kurang bervariasinya metode mengajar yang digunakan, kurang maksimalnya guru dalam memberikan stimulasi, serta guru yang cenderung lebih banyak berbicara yang kurang memberikan kesempatan kepada anak, dan kegiatan pembelajaran yang diterapkan lebih fokus pada calistung (membaca, menulis, dan menghitung) sehingga pembelajaran terlihat lebih monoton dan belum diintegrasikan melalui konsep dan metode bermain. Permasalahan-permasalahan tersebut merupakan hasil observasi dari penelitian yang dilakukan oleh Rahma pada tahun 2019 di KB Tunas Harapan Tanjung Bintang Lampung Selatan, dengan hasil observasi terdapat 14 dari 20 anak masih terlihat rendah dalam kemampuan bahasanya.

Berdasarkan permasalahan tersebut maka diperlukan metode yang cocok atau tepat untuk mengatasinya yaitu dengan menerapkan metode bermain melalui sebuah permainan bisik berantai untuk mengembangkan kemampuan bahasa anak dalam berkomunikasi. Piaget (Mulyati, 2012) berpendapat bahwa anak menciptakan sendiri pengetahuan mereka tentang dunianya yang sudah ia dengar. Dari pendapat di atas penggunaan teknik pembelajaran dengan komunikasi langsung melalui permainan bisik berantai dapat meningkatkan kemampuan berbahasa pada anak usia dini. Maka dari itu, penulis tertarik untuk melakukan pengkajian tentang analisis hubungan permainan bisik berantai terhadap kemampuan berbahasa anak usia dini.

\section{METODE}

Artikel jurnal ini menggunakan kajian pustaka, kajian pustaka dalam suatu penyusunan artikel adalah salah satu bagian penting dari keseluruhan langkah-langkah metode penelitian. Kajian pustaka yang penulis lakukan dalam penyusunan artikel ini adalah melalui: abstrak hasil penelitian yang kemudian penulis simpulkan bahan penelitian yang sudah dikelola sebelumnya, review jurnal yang relevan dengan topic yang dibahas penulis, dan dari berbagai macam buku referensi mengenai anak usia dini. Hal yang menjadi tantangan dalam penyusunan artikel jurnal ini adalah mengenai kurangnya sumber buku refrensi mengenai topik pembahasan terkait dengan perkembangan kemampuan berbahasa anak usia dini.

\section{HASIL DAN PEMBAHASAN}

\section{Karakteristik Kemampuan Berbahasa Anak Usia Dini}

Depdikbud (dalam Zubaidah) memaparkan bahwa bahasa merupakan ucapan pikiran dan perasaan manusia secara teratur, yang mempergunakan bunyi sebagai alatnya. Dengan demikian melalui pengertian tersebut melalui bahasa orang dapat saling berbincang bertukar cerita, pendapat serta ide. Hal ini juga tentunya dialami oleh seorang anak usia dini. Melalui bahasa, anak akan mengungkapkan kebutuhannya kepada orang-orang disekitarnya baik di lingkungan rumah, sekolah, maupun lingkungan di luar rumah. Selain itu menurut Jahja (Pebriana, 2017) kemampuan bahasa adalah suatu kemampuan untuk berkomunikasi, di mana pikiran dan perasaan dinyatakan dalam bentuk lambing atau symbol untuk mengungkapkan suatu pengertian seperti dengan menggunakan lisan, tulisan, isyarat, bilangan, lukisan, dan mimic muka. Artinya bahasa itu merupakan alat komunikasi bagi seorang anak untuk menyampaikan atau mengutarakan kebutuhannya.

Dalam buku metodik khusus pengembangan kemampuan berbahasa di TK disebutkan bahwa ruang lingkup pengembangan kemampuan berbahasa anak di TK yang dapat diberikan meliputi hal berikut: (Zubaidah,-)

a. Menirukan kembali urutan angka, urutan kata, b. Mengikuti beberapa perintah sekaligus, c. Menjawab pertanyaan, d. Menyanyikan lagu dan mengucapkan sajak, e. Mengenalkan kata tunjuk yang mengarah ke suatu tempa, f. Memeragakan gerakan sederhana dalam kehidupan anak sehari-hari, g. Menceritakan kejadian di sekitar anak secara sederhana, h. Menjawab pertanyaan sederhana dan cerita pendek yang disampaikan guru, i. Menceritakan kembali secara sederhana cerita pendek yang telah disampaikan guru, j. Memberikan 
keterangan/informasi tentang sesuatu hal, k. Memberi batasan tentang kata atau benda, 1 . Mengurutkan dan menceritakan isi gambar, m. Melengkapi kalimat sederhana, n. Melanjutkan cerita/sajak/lagu yang sudah dimulai guru, o. Menyebutkan sebanyakbanyaknya nama benda, binatang, tanaman yang mempunyai warna, bentuk, atau menurut ciri-ciri/sifat tertentu, p. Menyebutkan sebanyak-banyaknya kegunaan dari suatu benda, q. Membayangkan akibat dari suatu kejadian yang belum tentu terjadi, r. Menceritakan gambar yang telah disediakan, s. Menceritakan gambar yang dibuat sendiri, t. Mengekspresikan diri melalui dramatisasi, u. Mengucapkan suku kata dalam nyanyian, v. Mengenalkan huruf awal dari kata yang bermakna, w. Mengenalkan bunyi huruf akhir dari kata yang bermakna, x. Membuat kata dari suku kata awal yang disediakan dalam bentuk lisan, y. Mengenalkan lawan kata, z. Menggunakan kata ganti "aku" atau "saya"

Beberapa ruang lingkup di atas tentunya sangat perlu untuk dikembangkan bagi anak usia dini melalui berbagai metode yang dikemas semenarik mungkin oleh guru. Selain itu terdapat beberapa karakteristik kemampuan berbahasa anak usia 4-6 tahun, Hartati (2005) yaitu: dapat berbicara dengan kalimat sederhana yang lebih baik, dapat melaksanakan tiga perintah lisan secara sederhana, senang mendengarkan dan menceritakan cerita sederhana secara berurut dan mudah dipahami, menyebutkan jenis kelamin dan umur, menggunakan dan menjawab beberapa kata tanya, membandingkan dua hal, memahami hubungan timbal balik, mampu menyusun kalimat sederhana, serta mengenal tulisan sederhana. Adapun faktor yang mempengaruhi karakteristik kemampuan berbahasa anak usia dini menurut Tarmansyah (dalam Zubaidah,-), yaitu: kondisi jasmani dan kemampuan motorik, kesehatan umum, kecerdasan, sikap lingkungan, faktor social ekonomi, jenis kelamin, kedwibahasaan, dan neurologis. Kemampuan berbahasa seorang anak bukan suatu hal yang mudah untuk diperoleh, akan tetapi diperlukan melalui proses belajar yang unik baik itu dari faktor internal maupun eksternal yang terkadang diperoleh melalui proses belajar yang alami melalui kegiatankegiatan yang menarik.

\section{Metode Pengembangan Bahasa Anak Usia Dini}

Kemampuan berbahasa seorang anak akan terus berkembang jika distimulasi melalui kegiatan-kegiatan yang tepat dan menarik, serta memberikan kesempatan agar anak dapat belajar dengan alami. Proses belajar tersebut tentunya tidak hanya didapatkan anak melalui kesempatan yang bersifat formal dan informal. Pengembangan bahasa melalui kesempatan informal seperti anak lebih berinteraksi dengan lingkungan, berkomunikasi dengan teman dan orang dewasa yang ada disekitar anak. Selain itu untuk meningkatkan kemampuan berbahasa tentunya juga dapat diperoleh melalui kesempatan formal, melalui proses belajar disekolah. Untuk itu seorang guru tentunya harus menyediakan berbagai kegiatan yang menarik dan menciptakan suasana belajar bahasa yang memungkinkan adanya komunikasi antar abaj dengan guru maupun teman sebayanya. Maka dari itu seorang guru juga harus cakap dalam memilih metode yang dapat digunakan untuk mengembangkan bahasa anak usia dini. Metode pembelajaran yang dipilih harus disesuaiakan dengan kebutuhan seorang anak dan yang paling efektif untuk diterapkan.

Banyak cara atau metode yang dapat guru lakukan dalam meningkatkan kemampuan berbahasa anak sehingga anak mampu berbahasa dengan baik dan benar. Bermain merupakan salah satu metode dalam bentuk kegiatan yang dilakukan anak tanpa beban apapun, tanpa ada paksaan, penuh dengan canda tawa, penuh ekspresi dan memberikan kesenangan bagi anak. Melalui bermain anak dapat mengekspresikan segala bentuk kegiatannya dalam bentuk gerakan dan penuh keceriaan. Dalam hal ini bukan bermain yang hanya memberikan kesan bermain saja akan tetapi bermain yang bermakna, bermain yang sudah dikonsep sedemikian rupa untuk meningkatkan ke enam aspek perkembangan terutama aspek perkembangan bahasa. Metode bermain yang salah satu kegiatannya dapat digunakan 
untuk meningkatkan kemampuan berbahasa anak adalah melalui permainan bisik berantai.

Bisik berantai adalah suatu pesan yang dilakukan secara berantai. Permainan ini memiliki tujuan mempertajam keterampilan auditori dan berbicara (depdikas, dalam Rahma, 2019) secara umum permainan bisik berantai merupakan permainan yang dilakukan secara berkelompok, melalui cara membisikkan pesan dari teman yang satu ke teman yang lain. Selain itu menurut Djuanda (Hastuti, 2018) permainan bisik berantai ini adalah suatu permainan yang sebelumnya anak dibagi menjadi beberapa kelompok terlebih dahulu dan membisikkan pesan atau perintah kalimat atau kata kepada teman yang lain. Berdasarkan pendapat di atas dapat ditarik kesimpulan bahwa permainan bisik berantai adalah salah satu alternatif permainan dalam aspek perkembangan bahasa.

\section{Hubungan Metode Permainan Bisik Berantai dengan Kemampuan Berbahasa Anak Usia Dini}

Penelitian yang mendukung bahwa kemampuan berbahasa anak usia dini dapat ditingkatkan melalui metode bermain dalam bentuk kegiatan bermain bisik berantai adalah penelitian yang dilakukan oleh Rahma (2019) yang membuktikan melalui permainan bisik berantai kemampuan berbahasa anak dapat ditingkatkan. Aspek kemampuan bahasa yang diteliti dalam penelitian tersebut adalah berpartisipasi dalam percakapan, mengenal simbol-simbol, menyimak perkataan orang lain, menjawab pertanyaan sederhana dan membacakan gambar. Beberapa aspek tersebut menjadi poin penting untuk digunakan sebagai sarana berkomunikasi. Hal ini memberikan bukti bahwasannya aspek perkembangan bahasa memegang peranan penting dalam kehidupan anak usia dini, dan salah satu metode pengembangan yang dapat dilakukan pada anak usia dini adalah melalui metode bermain dengan permainan bisik berantai.

Rahma (2019) juga menyebutkan dalam penelitiannya bahwa dengan sesorang pandai berbahasa atau berbicara, maka ia akan dapat dengan mudah mempelajari ilmu pengetahuannya. Sama halnya dengan anak usia dini ketika kemampuan berbahasanya baik maka akan menunjang ke lima aspek yang lainnya. Melalui bahasa anak akan dengan mudah berinteraksi dengan lingkungannya. Dengan bahasa anak bias mengutarakan apa yang ada dipikirannya. Selain itu kemampuan untuk memahami atau menyimak perkataan dapat dikembangkan oleh guru melalui permainan bisik berantai. Hal ini diperkuat oleh penelitian yang dilakukan oleh Mulyati (2013). Melalui permainan bisik berantai anak diberikan kesempatan untuk memperagakan secara langsung sehingga dengan memperagakan permainan maka anak akan mendapatkan atau dapat merasakan manfaat permainan tersebut dan lebih berkesan bagi anak. Melalui permainan bisik berantai maka anak akan dengan mudah untuk menyampaikan dan memahami kata-kata sederhana. Hal yang tidak kalah penting untuk diperhatikan sehingga anak lebih merasa senang dalam memahami atau menyimak sesuatu dibandingkan dengan metode ceramah yang terkesan menjenuhkan dan cepat membuat anak bosan.

Permainan bisik berantai tidak hanya untuk meningkatkan kemampuan memahami atau menyimak kata. Akan tetapi juga dapat meningkatkan kemampuan bahasa untuk menyampaikan pesan dari teman satu keteman yang lainnya. Melalui permainan bisik berantai keterampilan berbicara anak dapat meningkat seperti untuk memahami dan menyampaikan suatu kata sederhana yang ada di dalam pesan. Hal tersebut dikuatkan oleh Zubaidah (2017) dalam penelitiannya yang berjudul peningkatan kemampuan berbicara melalui permainan bisik berantai siswa kelompok A di TK mahardika simo kerto Surabaya, penelitian tersebut menunjukkan keefektifan permainan bisik berantai dalam peningkatan kemampuan berbahasa anak usia dini. Jefree dkk (dalam Rahma, 2019) mengungkapkan permainan bisik berantai memiliki power atau kekuatan untuk melatih kemampuan menyimak anak dari perkataan orang lain, sekaligus memperhatikan ketepatan dan keakuratan pesan yang disampaikan oleh 
anak, menambah perbendaharaan kata atau kosa kata, sehingga keterampilan berbahasa anak dapat terlatih dengan penuh keceriaan tanpa adanya paksaan.

Dari beberapa hasil penelitian yang telah dilakukan maka dapat penulis tarik kesimpulan bahwa terdapat hubungan antara metode bermain melalui permainan bisik berantai yang diterapkan dengan peningkatan kemampuan berbahasa anak usia dini. Karena melalui kegiatan bermain bisik berantai anak dapat secara langsung memahami dan menyampaikan pesan yang telah anak dengar. Hal ini tentunya juga akan berdampak bagi pemerolehan kata atau kosa kata baru sehingga anak dapat berkomunikasi dan mengeskpresikan apa isi yang ada di dalam pesan tersebut. Sehingga permainan bisik berantai ini dapat dijadikan alternative guru untuk meningkatkan kemampuan berbahasa anak usia dini.

\section{SIMPULAN}

Pada hakikatnya pendidikan anak usia dini adalah pemberian upaya membimbing, mendidik dan memberi stimulus dalam proses pembelajaran melaluia aktivitas kegiatan yang unik, menarik, dan menyenangkan. Salah satu perkembangan yang harus difasilitasi oleh guru adalah perkembangan bahasa anak. Permainan bisik berantai mencakup peningkatan kemampuan menyimak atau memahami kata, anak dapat menyampaikan isi kata yang dia dengar, dan juga tentunya anak mendapat banyak pemerolehan kosa kata baru. Maka melalui permainan bisik berantai dapat penulis simpulkan merupakan salah satu aktivitas kegiatan unik dan menarik dalam meningkatkan kemampuan berbahasa anak usia dini.

\section{REFERENSI}

Hartati, Sofia. (2005). Perkembangan Belajar pada Anak Usia Dini. Jakarta: Direktorat Pendidikan Tinggi Departemen Pendidikan Nasional.

Hastuti, E.W., \& Kusumanintyas, L.E. (2017). Meningkatkan

Perkembangan Bahasa Anak Usia
4-5 Tahun Melalui Bermain Pesan Berantai. JURNAL AUDI:

Jurnal Ilmiah Kajian Ilmu Anak dan Media Informasi PAUD. 2(2), 9197

Mulyati. (2012). Peningkatan Kemampuan Menyimak Anak melalui Permainan Bisik Berantai di TK Taufiq Perguruan IslamBayur. Jurnal Ilmiah Pesona PAUD. 1

Pebriana, P. H. (2017). Analisis Kemampuan Berbahasa dan Penanaman Moral pada Anak Usia Dini melalui Metode Mendongeng. Jurnal Obsesi : Jurnal Pendidikan Anak Usia Dini. https://doi.org/10.31004/obsesi.v1i2. $\underline{34}$

Rahma, Zahratur. (2019). Penerapan Permainan Bisik Berantai untuk Mengembangkan Bahasa

Anak Usia 5-6 Tahun di KB Tunas Harapan Tanjung Bintang Lampung Selatan. (skripsi). Universitas Islam Negeri Raden Intan Lampung, Lampung

Zubaidah, Enny. (-). Draft Buku Pengembangan Bahasa Anak Usia Dini. Universitas Negeri Yogyakarta: Yogyakarta 